\title{
STRESS: AN ANALYSIS OF ITS SOURCE AND INFLUENCE
}

\author{
R. L. THOMAS, J. E. GRAFIUS and S. K. HAHN* \\ Michigan State University
}

Received 24.vii.70

\section{INTRODUGTION}

ANY non-superficial analysis of a complex character such as crop yield should involve consideration of its components although such treatment is apt to become somewhat bewildering as the number of component characters increases. The main source of apparent confusion is that the components form part of a dynamic and complex interacting system, any part of which may be influenced by genotype, environment or their interaction. To add to any difficulties the obvious variables within the system are not merely the measured components of the complex trait but all possible correlations between components; here we wish to use the terms correlation and stress interchangeably. These two types of variables are not numerically directly comparable. One approach toward decreasing the pattern of complexity is to set one category of variables, namely the correlations, all to zero, i.e. remove the limitation of stress forces. A technique is available for doing this (Thomas, Grafius and Hahn, 1970). The $n$th character in the sequence may thus be expressed with and without stress and the difference between these quantities can be considered as the measure of stress on that character.

In this paper we wish to examine the source of stress and its influence on sequential multiplicative characters. In initiating such an undertaking we attempt to uncover the relative roles of genotype, environment and their interaction in forming these internal correlations or stress forces. Suitable data were obtained from an experiment with rice in Korea and an experiment with winter barley in Michigan, U.S.A. Both sets of data involve yield and its components.

\section{Materials AND methods}

The rice data were supplied by the Crop Research Station, Office of Rural Development, Korea, and constitute replicated estimates of three components of yield for each of 12 Korean lines in each of six environments. The components are $X$, the number of heads per plant (which is equivalent in this case to heads per unit area since the crop is transplanted- -5 seedlings per 72 square inches); $Y$, the number of seeds per head and $Z$ the average seed weight (in mg. $\times 100$ ). Thus, $X, Y$ and $Z$ are multiplicative and their product is exactly yield per plant, or per unit area. The barley data consisted of a set of lines grown in different locations in Michigan, U.S.A. Since in two of these environments replication was not effected, a variable number (between 4 and 18) selected sublines were regarded as replications of each cross, within each environment. Only two components, number of seeds/unit area $(X Y)$ and average seed weight $(Z)$ were available; again their product exactly equals yield per unit area.

* Presently professor, Suwon University, Korea. 

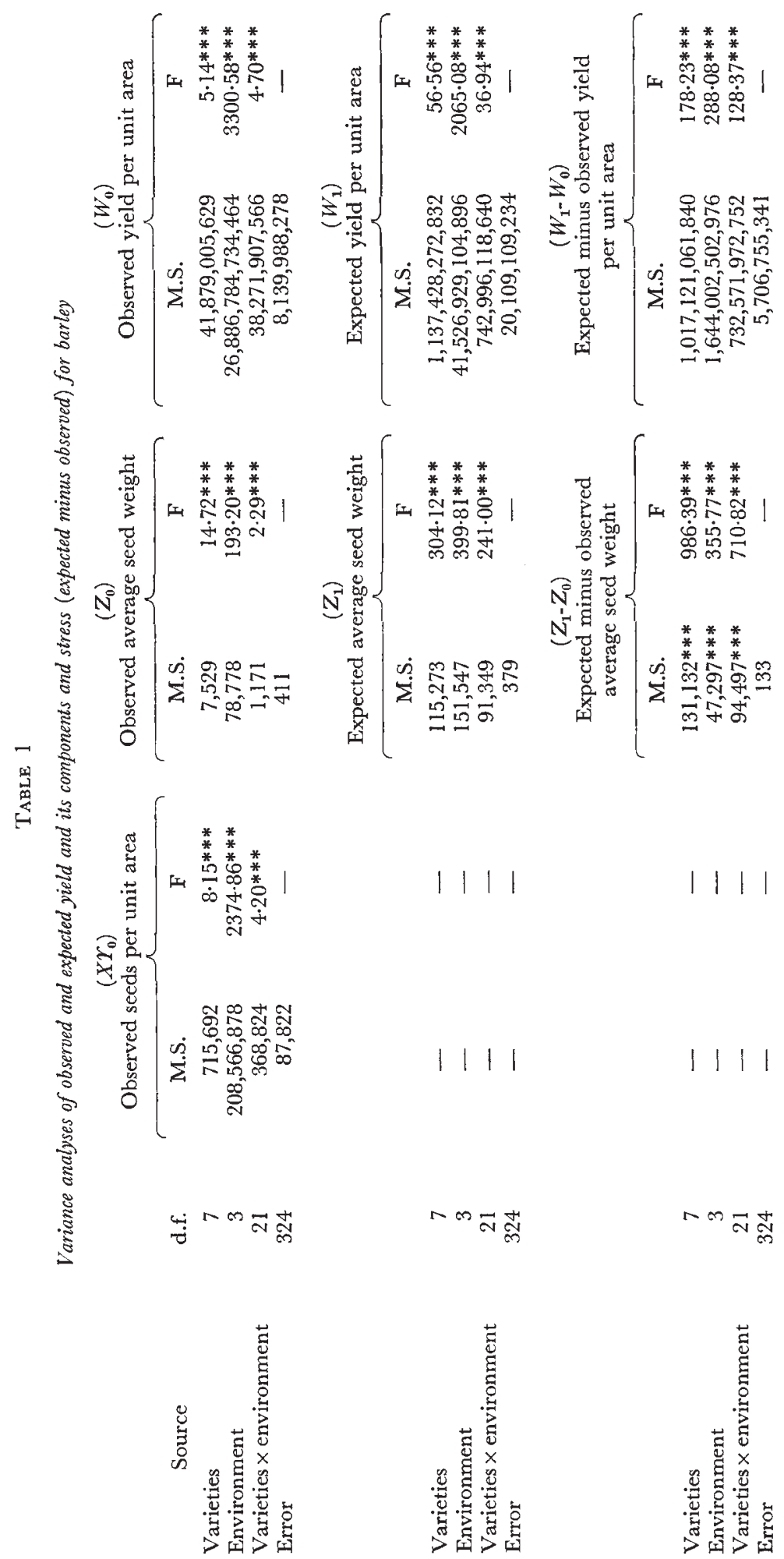
The technique used for removing the influence of correlations has already been described (Thomas, Grafius and Hahn, 1970). These transformations were applied separately to the replicated data for each line within each environment for both sets of data.

The method of transformation removes the correlated effects of the first trait from the second trait and the effects of the first and the second traits from the third trait, etc. Hence $X$ for rice and $X Y$ for barley are unchanged, but subsequent traits are transformed. Conventional analysis of variance of the transformed and the untransformed data-referred to as expected and observed respectively and of the difference between them are presented in tables 1 and 3 . The estimates of variance components for variety (a collective term used to denote crosses, lines or actual varieties),

TABLE 2

Calculated variance components in percentage (from Table 1) for barley

\begin{tabular}{|c|c|c|c|c|}
\hline \multirow[b]{2}{*}{ Source } & \multicolumn{3}{|c|}{ Component } & \\
\hline & $x r$ & $z$ & $W$ & \\
\hline $\begin{array}{l}\text { Genotype } \\
\text { Environment } \\
\text { Genotype } \times \text { environment }\end{array}$ & $\begin{array}{r}0.6 \\
98 \cdot 7 \\
0.7\end{array}$ & $\begin{array}{r}14 \cdot 4 \\
80 \cdot 2 \\
5 \cdot 4\end{array}$ & $\begin{array}{r}0.2 \\
98 \cdot 9 \\
0.9\end{array}$ & Observed variables \\
\hline $\begin{array}{l}\text { Genotype } \\
\text { Environment } \\
\text { Genotype } \times \text { environment }\end{array}$ & - & $\begin{array}{l}20 \cdot 2 \\
13 \cdot 8 \\
66 \cdot 0\end{array}$ & $\begin{array}{r}4 \cdot 5 \\
83 \cdot 8 \\
11 \cdot 7\end{array}$ & Expected variables \\
\hline $\begin{array}{l}\text { Genotype } \\
\text { Environment } \\
\text { Genotype } \times \text { environment }\end{array}$ & - & $\begin{array}{r}24 \cdot 2 \\
4 \cdot 5 \\
71 \cdot 2\end{array}$ & $\begin{array}{l}21 \cdot 4 \\
17 \cdot 3 \\
61 \cdot 3\end{array}$ & $\begin{array}{c}\text { Stress } \\
\text { (expected minus observed) }\end{array}$ \\
\hline
\end{tabular}

environment and variety $\times$ environment are shown in tables 2 and 4 . These were derived from a conventional mean square estimation from tables 1 and 3. The model used to estimate these components assumes fixed environmental and variety effects. Thus: in tables 1 and 3: Variety M.S. $=\sigma^{2}$ error $+s e o_{v}^{2}$; Environment M.S. $=\sigma^{2}$ error $+s v \sigma_{e}^{2}$; Genotype $\times$ Environment M.S. $=\sigma^{2}$ error $+s \sigma_{v e}^{2}$ and the error of course $=\sigma^{2}$ error. The coefficients refer to: $s$, the number of samples of each variety in each environment, $v$ the number of varieties and $e$ the number of environments. Thus the appropriate tests in tables 1 and 3 are against the error term. The components $\sigma_{v}^{2}, \sigma_{e}^{2}$ and $\sigma_{v e}^{2}$ were totalled and each expressed as a percentage of this quantity to obtain an idea of their relative magnitudes (tables 2 and 4). Further analyses of the data are discussed in the next section.

\section{Results}

\section{(i) Barley}

The variance analysis of the observed components $X Y$ and $Z$ and yield $(W)$ in table 1 indicates a relatively small though highly significant contribution of genotype $x$ environment interaction to the expression of all these variables. In all three instances a highly significant genotype contribution is observable. However, the most important factor influencing 

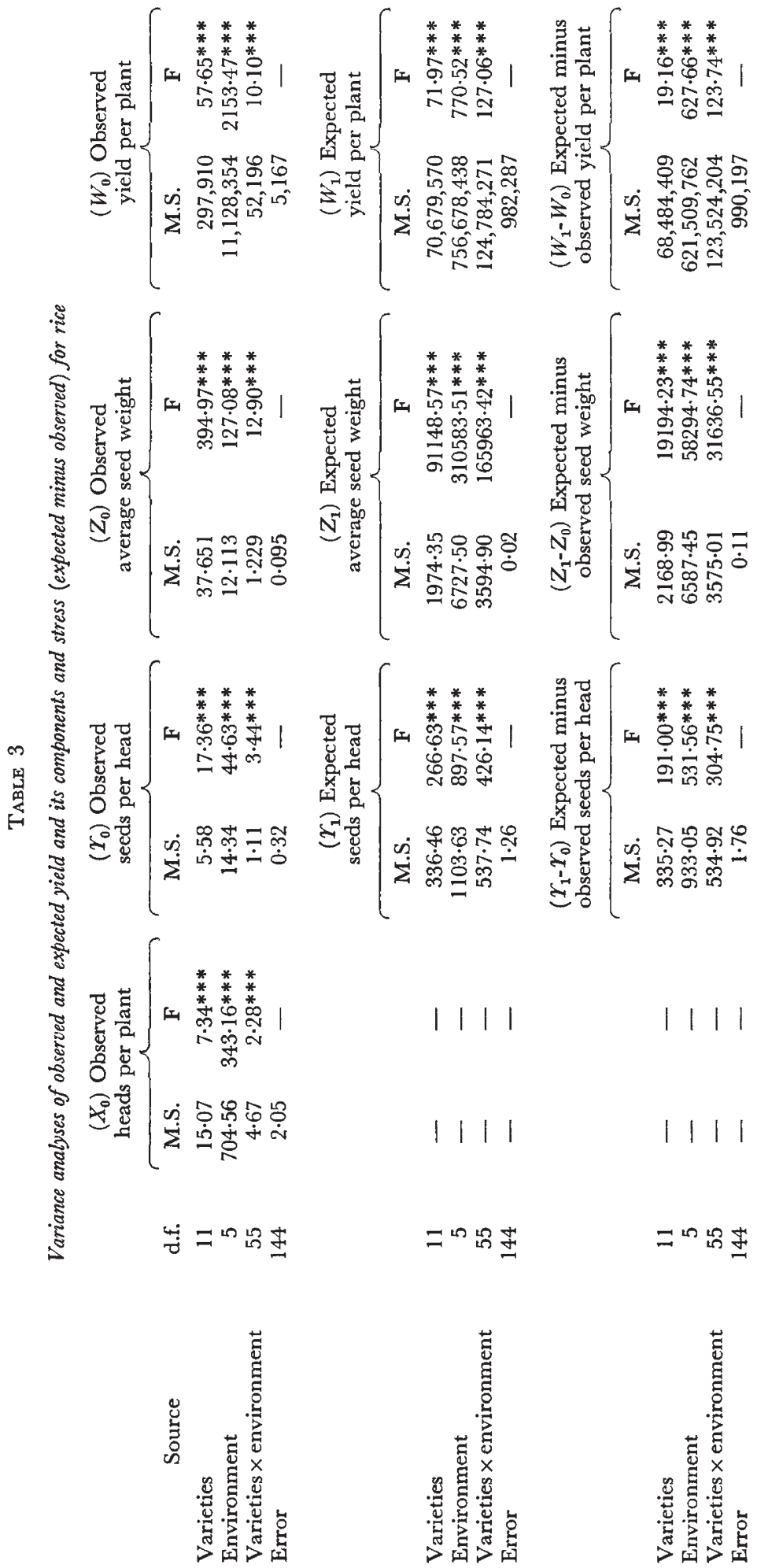
all these characters is obviously environment-as seen from the highly significant and extremely large values for this component in the $F$ test and from the component analysis shown in table 2-where the relative magnitude of genotype, environmental and genotype $\times$ environmental components is indicated.

The " expected" values of $Z$ and $W$ are also analysed in table 1 and the relative magnitudes of the components indicated in table 2 . We should perhaps reiterate at this stage the interpretation of these expected variables. The expected value of $Z$ represents the value obtained when the influence of $X Y$ is removed and thus the "true ", direct influence of source variation on this yield component may be ascertained. The value of $W$ similarly

TABLE 4

Calculated variance component values in percentages (from Table 3) for rice

\begin{tabular}{|c|c|c|c|c|c|}
\hline \multirow[b]{2}{*}{ Source } & \multicolumn{4}{|c|}{ Component } & \\
\hline & $X$ & $r$ & $z$ & $W$ & \\
\hline Genotype & $3 \cdot 2$ & $31 \cdot 0$ & $75 \cdot 0$ & $4 \cdot 8$ & \\
\hline Enviroment & $86 \cdot 7$ & $41 \cdot 2$ & $12 \cdot 0$ & $90 \cdot 6$ & Observed variables \\
\hline Genotype $\times$ environment & $10 \cdot 1$ & $27 \cdot 8$ & $13 \cdot 0$ & $4 \cdot 6$ & \\
\hline Genotype & - & $8 \cdot 0$ & $7 \cdot 4$ & $6 \cdot 0$ & \\
\hline Environment & - & $13 \cdot 1$ & $12 \cdot 6$ & $31 \cdot 7$ & Expected variables \\
\hline Genotype $\times$ environment & - & $78 \cdot 9$ & $80 \cdot 0$ & $62 \cdot 3$ & \\
\hline Genotype & - & $8 \cdot 3$ & $8 \cdot 1$ & $5 \cdot 8$ & Stress \\
\hline Environment & - & $11 \cdot 7$ & $12 \cdot 2$ & $28 \cdot 2$ & (expected minus observed) \\
\hline Genotype $\times$ environment & - & $80 \cdot 0$ & $79 \cdot 7$ & $66 \cdot 0$ & \\
\hline
\end{tabular}

allows the true influence of source variation on yield to be ascertained-in this case the product of observed $X Y$ and expected $Z$ being analysed. Evidently the removal of $X Y$ influence from $Z$ vastly inflates the relative contribution of genotype $\times$ environmental components, primarily at the expense of the environmental influence; the genotypic source also appears slightly inflated. Thus the situation appears completely different from that of the observed $Z$. The observed $Z$ mirrors the variation source of $X Y$ and where analysed in its "own right" the main influence on its real expression over and above the effect of $X Y$ is found in the genotype $x$ environment interaction (table 2 , expected).

The situation for expected yield does not change as drastically as $Z$, probably due to the inclusion of observed $X Y$ in its estimation. However, the magnitude of the previously observed large environmental influence does seem to have been slightly decreased and the genotype $\times$ environment influence as well as the genotypic influence correspondingly increased.

Consider now the analysis of expected minus observed $Z$ and $W$. This difference is interpreted as the measure of internal, between component, stress. The main comments to be made from tables 1 and 2 is that genotype $x$ environment interaction is a major source of influence over stress operating on $Z$ with a slight though significant environmental influence and a somewhat larger genotypically controlled effect. Much the same may be said for $W$, although here the contribution of environment and genotype are approximately equal and are about one-third as influential as their interaction. 
No further analysis of stress or indeed the expected and observed values of the characters is undertaken here for barley. We may sum up and conclude that the main source of stress derives from the interaction of genotype and environment, but environment and genotype do have a significant influence in their own right. Whether these interactions are directed or random we will not consider for this set of data-although this is a question we will attempt to answer for the following rice data.

\section{(ii) Rice}

Similar analyses to those described for barley are shown in tables 3 and 4 for rice yield and its three components. Analysis of the observed data indicate that, for all three components $X, Y$ and $Z$, and yield $(W)$ genotype $\times$ environment interaction is fairly low-accounting for between 5 per cent. of total variation of $W$ to 30 per cent. of the variation of $Y$. Both varietal and environmental influence are highly significant for all four characters, the latter, with the exception of $Z$, accounting for the higher proportion of observed variation.

Removing the influence of correlation changes the analytical situation for the transformed components $Y$ and $Z$ and for expected $W$. In general, both genetic effects and environmental influence are considerably reduced though still significant. The contribution of genotype $\times$ environment interaction, on the other hand, is increased to very high levels accounting for between 60 per cent. and 80 per cent. of the variation. The observed genetic variation in $T, Z$ and $W$ mainly reflects the influence of internal correlation between components, in this case primarily the influence of $X$. Similarly, the large environmental contribution to observed $r, Z$ and $W$ largely reflects the effect of such environment on $X$. The relative contribution of genotype $\times$ environment interaction to the components $Y, Z$ and to $W$ is enhanced by the removal of the effects of correlations.

As for the barley data, the source of stress for the rice components $r$, $Z$ and for $W$ is primarily vested in the interaction of genotypes with environments. In the analyses of expected minus observed variables a minor though significant genotype influence and environmental contribution is discernible.

In this experiment, since there is evidence for a genetic contribution to stress formation, we chose to proceed with a further breakdown of the genotype $\times$ environmental contribution to elucidate its nature-whether it is directed or random. Only one character, yield, is analysed by way of illustration and the basic values for expected minus observed yield are included in table 5. The procedure used is the regression analysis developed by Yates and Cochran (1938), Finlay and Wilkinson (1963) and Perkins and Jinks (1968)-the model of the latter authors being adopted. The technique involves regressing the deviations due only to genotype $\times$ environment interaction of the $n$th line against those due to the average environmental deviation (from the experimental mean) of all lines. The deviations are separated into linear (regression) and non-linear (residual), and the former tested against the latter, and the latter tested against the pooled estimate of within line, within environment error. These tests are shown in table 6 . The residual, non-linear and thus unpredictable variation is significant for all 12 varieties. However, the regression M.S. is larger than 
the residual M.S. for roughly half the varieties-and is significantly so for varieties 1, 3, 8 and 9 . For these latter varieties, at least, there can be said to exist a linear, predictable change in genotypically determined stress values varying systematically with observed changes in the average degree of environmentally induced stress.

TABLE 5

Table of mean values for observed yield (upper values) and stress (expected minus observed) (lower values) for rice varieties in different environments

\begin{tabular}{|c|c|c|c|c|c|c|c|}
\hline \multirow[b]{2}{*}{ Variety } & \multicolumn{6}{|c|}{ Environment } & \multirow{2}{*}{$\begin{array}{c}\text { Overall } \\
\text { mean }\end{array}$} \\
\hline & 1 & 2 & 3 & 4 & 5 & 6 & \\
\hline 1 & $\begin{array}{l}1017 \\
1507\end{array}$ & $\begin{array}{r}1960 \\
414\end{array}$ & $\begin{array}{r}1008 \\
927\end{array}$ & $\begin{array}{r}659 \\
2706\end{array}$ & $\begin{array}{l}1984 \\
2179\end{array}$ & $\begin{array}{r}2254 \\
28715\end{array}$ & $\begin{array}{l}1480 \\
4863\end{array}$ \\
\hline 2 & $\begin{array}{r}987 \\
7312\end{array}$ & $\begin{array}{r}1633 \\
-8344\end{array}$ & $\begin{array}{r}933 \\
3501\end{array}$ & $\begin{array}{r}677 \\
1406\end{array}$ & $\begin{array}{l}1843 \\
2462\end{array}$ & $\begin{array}{r}2137 \\
15756\end{array}$ & $\begin{array}{l}1368 \\
3682\end{array}$ \\
\hline 3 & $\begin{array}{l}1088 \\
4819\end{array}$ & $\begin{array}{l}2073 \\
2684\end{array}$ & $\begin{array}{r}1674 \\
516\end{array}$ & $\begin{array}{r}680 \\
-5512\end{array}$ & $\begin{array}{r}2107 \\
13246\end{array}$ & $\begin{array}{r}2375 \\
19962\end{array}$ & $\begin{array}{l}1666 \\
5952\end{array}$ \\
\hline 4 & $\begin{array}{l}997 \\
333\end{array}$ & $\begin{array}{l}1496 \\
1978\end{array}$ & $\begin{array}{r}597 \\
1753\end{array}$ & $\begin{array}{r}765 \\
6733\end{array}$ & $\begin{array}{r}1664 \\
12686\end{array}$ & $\begin{array}{l}1960 \\
2717\end{array}$ & $\begin{array}{l}1247 \\
4367\end{array}$ \\
\hline 5 & $\begin{array}{r}1021 \\
31\end{array}$ & $\begin{array}{r}1537 \\
-3838\end{array}$ & $\begin{array}{l}871 \\
533\end{array}$ & $\begin{array}{r}589 \\
3294\end{array}$ & $\begin{array}{r}1935 \\
14985\end{array}$ & $\begin{array}{l}1884 \\
7057\end{array}$ & $\begin{array}{l}1306 \\
3677\end{array}$ \\
\hline 6 & $\begin{array}{r}997 \\
4477\end{array}$ & $\begin{array}{l}1751 \\
5038\end{array}$ & $\begin{array}{l}1363 \\
2080\end{array}$ & $\begin{array}{l}568 \\
103\end{array}$ & $\begin{array}{l}1832 \\
3404\end{array}$ & $\begin{array}{r}2145 \\
21669\end{array}$ & $\begin{array}{l}1443 \\
4994\end{array}$ \\
\hline 7 & $\begin{array}{l}999 \\
573\end{array}$ & $\begin{array}{l}1829 \\
3766\end{array}$ & $\begin{array}{l}1292 \\
2048\end{array}$ & $\begin{array}{l}611 \\
687\end{array}$ & $\begin{array}{l}2004 \\
5601\end{array}$ & $\begin{array}{l}2279 \\
3673\end{array}$ & $\begin{array}{l}1502 \\
1278\end{array}$ \\
\hline 8 & $\begin{array}{l}1038 \\
1642\end{array}$ & $\begin{array}{l}1679 \\
-21\end{array}$ & $\begin{array}{l}1176 \\
3494\end{array}$ & $\begin{array}{r}624 \\
-756\end{array}$ & $\begin{array}{r}1695 \\
-1584\end{array}$ & $\begin{array}{r}1966 \\
-3278\end{array}$ & $\begin{array}{l}1363 \\
-83\end{array}$ \\
\hline 9 & $\begin{array}{l}994 \\
148\end{array}$ & $\begin{array}{l}1801 \\
7283\end{array}$ & $\begin{array}{r}1268 \\
-290\end{array}$ & $\begin{array}{r}666 \\
-92\end{array}$ & $\begin{array}{l}1724 \\
4472\end{array}$ & $\begin{array}{l}2063 \\
2333\end{array}$ & $\begin{array}{r}1419 \\
818\end{array}$ \\
\hline 10 & $\begin{array}{r}1075 \\
-259\end{array}$ & $\begin{array}{r}1721 \\
-72\end{array}$ & $\begin{array}{l}1175 \\
4201\end{array}$ & $\begin{array}{r}639 \\
-307\end{array}$ & $\begin{array}{l}1838 \\
1262\end{array}$ & $\begin{array}{r}2060 \\
24137\end{array}$ & $\begin{array}{l}1418 \\
4826\end{array}$ \\
\hline 11 & $\begin{array}{l}1076 \\
1182\end{array}$ & $\begin{array}{l}1815 \\
3270\end{array}$ & $\begin{array}{l}1364 \\
2634\end{array}$ & $\begin{array}{r}667 \\
1563\end{array}$ & $\begin{array}{r}1915 \\
24406\end{array}$ & $\begin{array}{r}2089 \\
203\end{array}$ & $\begin{array}{l}1488 \\
5543\end{array}$ \\
\hline 12 & $\begin{array}{r}900 \\
-1458\end{array}$ & $\begin{array}{r}1371 \\
996\end{array}$ & $\begin{array}{l}1074 \\
2194\end{array}$ & $\begin{array}{r}512 \\
4257\end{array}$ & $\begin{array}{r}1427 \\
11751\end{array}$ & $\begin{array}{l}1776 \\
6862\end{array}$ & $\begin{array}{l}1177 \\
4100\end{array}$ \\
\hline $\begin{array}{c}\text { Overall } \\
\text { mean }\end{array}$ & $\begin{array}{l}1016 \\
1596\end{array}$ & $\begin{array}{r}1722 \\
468\end{array}$ & $\begin{array}{l}1149 \\
1811\end{array}$ & $\begin{array}{l}638 \\
722\end{array}$ & $\begin{array}{l}1831 \\
6593\end{array}$ & $\begin{array}{r}2082 \\
10817\end{array}$ & $\begin{array}{l}1407 \\
3668\end{array}$ \\
\hline
\end{tabular}

The last question we wish to answer is whether the degree of stress is related to the magnitude of yield. In table 5 the highest observed yields are generally though not invariably associated with the higher stress. This relationship is most marked in the environment total (over all varieties) row and here the correlation between observed stress and yield is:

$$
r(4 \text { d.f. })=0 \cdot 746
$$

thus indicating that the environments generating the greater stress produce the higher yields. A similar relationship would appear to hold for varieties 
(summed over environments), the higher yielding varieties possessing the greater stress. The correlation in this instance although still positive is small and nonsignificant $(r(10$ d.f. $)=0.210)$ and the situation although improved does not indicate a really strong association when the rank correlation is calculated $(r(10$ d.f. $)=0.423)$.

TABLE 6

Analysis of stability of (yield) stress in each of 12 rice varieties

\begin{tabular}{|c|c|c|c|c|c|}
\hline & Source & d.f. & M.S. & $\mathrm{F}+\dagger$ & $\mathrm{F}+\mathrm{T}^{+}$ \\
\hline $\begin{array}{c}\text { Variety } \\
1\end{array}$ & $\begin{array}{l}\text { Regression } \\
\text { Residual }\end{array}$ & $\begin{array}{l}1 \\
4\end{array}$ & $\begin{array}{r}197,548,999 \\
38,240,450\end{array}$ & $\begin{array}{r}199 \cdot 47 * * * \\
38 \cdot 62 * * *\end{array}$ & $5 \cdot 16 \dagger$ \\
\hline $\begin{array}{c}\text { Variety } \\
2\end{array}$ & $\begin{array}{l}\text { Regression } \\
\text { Residual }\end{array}$ & $\begin{array}{l}1 \\
4\end{array}$ & $\begin{array}{l}13,740,254 \\
35,377,649\end{array}$ & $\begin{array}{l}1 \cdot 38 \\
3 \cdot 56 * *\end{array}$ & $0 \cdot 38$ \\
\hline $\begin{array}{c}\text { Variety } \\
3\end{array}$ & $\begin{array}{l}\text { Regression } \\
\text { Residual }\end{array}$ & $\begin{array}{l}1 \\
4\end{array}$ & $\begin{array}{l}97,721,454 \\
13,674,302\end{array}$ & $\begin{array}{l}98 \cdot 68 * * * \\
13 \cdot 80 * * *\end{array}$ & $7 \cdot 15 \dagger$ \\
\hline $\begin{array}{c}\text { Variety } \\
4\end{array}$ & $\begin{array}{l}\text { Regression } \\
\text { Residual }\end{array}$ & $\begin{array}{l}1 \\
4\end{array}$ & $\begin{array}{l}41,566,296 \\
24,563,584\end{array}$ & $\begin{array}{l}41 \cdot 99 * * * \\
24 \cdot 80 * * *\end{array}$ & 1.69 \\
\hline $\begin{array}{c}\text { Variety } \\
5\end{array}$ & $\begin{array}{l}\text { Regression } \\
\text { Residual }\end{array}$ & $\begin{array}{l}1 \\
4\end{array}$ & $\begin{array}{r}1,042,369 \\
28,191,360\end{array}$ & $\begin{array}{c}1.05 \\
28 \cdot 47 * * *\end{array}$ & $0 \cdot 04$ \\
\hline $\begin{array}{c}\text { Variety } \\
6\end{array}$ & $\begin{array}{l}\text { Regression } \\
\text { Residual }\end{array}$ & $\begin{array}{l}1 \\
4\end{array}$ & $\begin{array}{r}9,794,401 \\
56,750,361\end{array}$ & $\begin{array}{c}9 \cdot 89 * * \\
57 \cdot 31 * * *\end{array}$ & $0 \cdot 17$ \\
\hline $\begin{array}{c}\text { Variety } \\
7\end{array}$ & $\begin{array}{l}\text { Regression } \\
\text { Residual }\end{array}$ & $\begin{array}{l}1 \\
4\end{array}$ & $\begin{array}{r}15,235,277 \\
6,302,569\end{array}$ & $\begin{array}{l}15 \cdot 39 * * * \\
63 \cdot 63 * * *\end{array}$ & $2 \cdot 41$ \\
\hline $\begin{array}{c}\text { Variety } \\
8\end{array}$ & $\begin{array}{l}\text { Regression } \\
\text { Residual }\end{array}$ & $\begin{array}{l}1 \\
4\end{array}$ & $\begin{array}{r}172,364,824 \\
3,489,314\end{array}$ & $\begin{array}{c}174 \cdot 12 * * * \\
3 \cdot 52 * *\end{array}$ & $49 \cdot 40 * *$ \\
\hline $\begin{array}{c}\text { Variety } \\
9\end{array}$ & $\begin{array}{l}\text { Regression } \\
\text { Residual }\end{array}$ & $\begin{array}{l}1 \\
4\end{array}$ & $\begin{array}{r}129,001,094 \\
17,576,727\end{array}$ & $\begin{array}{r}130 \cdot 29 * * * \\
17 \cdot 73 * * *\end{array}$ & $7 \cdot 33 \dagger$ \\
\hline $\begin{array}{c}\text { Variety } \\
10\end{array}$ & $\begin{array}{l}\text { Regression } \\
\text { Residual }\end{array}$ & $\begin{array}{l}1 \\
4\end{array}$ & $\begin{array}{l}81,356,018 \\
31,732,768\end{array}$ & $\begin{array}{l}82 \cdot 17 * * * \\
32 \cdot 05 * * *\end{array}$ & $2 \cdot 57$ \\
\hline $\begin{array}{c}\text { Variety } \\
11\end{array}$ & $\begin{array}{l}\text { Regression } \\
\text { Residual }\end{array}$ & $\begin{array}{l}1 \\
4\end{array}$ & $\begin{array}{r}14,921,635 \\
100,838,680\end{array}$ & $\begin{array}{r}15 \cdot 06 * * * \\
101 \cdot 85 * * *\end{array}$ & $0 \cdot 14$ \\
\hline $\begin{array}{c}\text { Variety } \\
12\end{array}$ & $\begin{array}{l}\text { Regression } \\
\text { Residual }\end{array}$ & $\begin{array}{l}1 \\
4\end{array}$ & $\begin{array}{r}4,483,981 \\
14,724,089\end{array}$ & $\begin{array}{c}4 \cdot 53 * \\
14 \cdot 87 * * *\end{array}$ & 0.30 \\
\hline$X$ & Error & 144 & 990,197 & \multicolumn{2}{|c|}{$\begin{array}{l}\mathrm{F} \dagger \dagger=\text { test against error } \\
\mathrm{F} \dagger \dagger \dagger=\text { test against residual }\end{array}$} \\
\hline
\end{tabular}

\section{Discussion}

It is evident from the previous section that the removal of stress, from sequential and complex characters in the two experiments, allows the expression of the true influence of source variation on these transformed variables to be examined. In both cases the uncomplicated main effects of genotype and environment, particularly the former, are usually considerably reduced and the more complex forces of genotype $\times$ environmental variation play a correspondingly greater role. Thus stress can be regarded in the present instance as a force tending to " disguise" the true nature of 
the source of control over the expression of the second and subsequent characters in a developmental sequence. It is not however envisaged that the control over the first character in the sequence will invariably have such a profound influence in reflecting its source control into the apparent control over subsequent characters. Indeed, the degree of reflective power of any character and its susceptibility to reflection will depend on many variables, e.g. its heritability, the strength of the correlations, its relative developmental importance, etc.

Stress itself would seem in these experiments to be primarily influenced by a complex interaction of genotype and environment-but this is coupled with genotypic control over differences in stress. However, there are also environmental differences in stress level which would apparently control to some degree the mean stress input on all genotypes within a specified environment. This latter finding allows us to be rather optimistic about the utilisation of stress in predicting genotypic values. The main variation between genotypes should be attributable to the input of, in this case, the differences in the first character in the sequence plus a general stress pattern, primarily, though not exclusively determined by environment. Thus knowing the stress situation for a given environment and the potential varietal values for the main determinant character in the sequence the values for subsequent characters and the complex character should be predictable.

The analysis for stability of stresses operating on rice yield was somewhat encouraging. For at least some of the lines examined genotype $\times$ environment interaction for stress appears to be a linear function of the environmental tress and thus the change in stress pattern within these particular genotypes is predictable from environment to environment. For other lines the larger significance of the residual M.S. implies that in these cases no easy predictive basis is available across environments.

The level of stress characterising particular genotypes and environments appears to be positively correlated with the level of yield obtained for the rice experiment; the relationship being stronger for environments. This is not entirely unexpected and clearly illustrates the points made in a recent paper by Grafius (1969).

\section{Summary}

1. Variance and component analyses of sequential characters within the structure of conventional genotype environment situations are presented.

2. The analyses are carried out at three levels for each character, firstly on the observed values for the trait, secondly on the trait with the intercharacter correlations removed, and lastly on the difference between the untransformed (correlated) and transformed (uncorrelated) values.

3. Considerable differences in the form of control over the uncorrelated as opposed to the correlated traits are revealed for both crops for both component traits and complex traits.

4. Generally the relative contribution of the main effects of genotype and environment are substantially reduced and the interaction of genotype $x$ environment plays a correspondingly greater role over the expression of the transformed as opposed to the untransformed traits. 
5. Although there are direct main effect contributions of the genotypic and environmental forces to stress or correlation formation the primary influence would appear to be due to a complex interaction of the genotype $x$ environment source.

6. The level of stress is shown to be positively associated with the yield levels in rice.

Acknowledgments.-.Published as article number 5001 of Michigan State University Agricultural Experiment Station. We wish to acknowledge the advice and help of Dr M. W. Adams, Dr C. M. Harrison, Dr C. Lee and Mr J. Barnard in the preparation of this manuscript. This work was partially funded by the Malting Barley Improvement Association.

\section{REFERENCES}

FINLAY, K. W., AND WILkINSON, G. N. 1963. The analysis of adaptation in plant breeding programs. Aust. 7. Agr. Res., 14, 742-754.

GRAFIUS, J. E. 1969. Stress: A necessary ingredient of genotype $\times$ environment interaction. Proc. Second Int. Barley Conference Washington 1969 (in press).

PERKINS, J. M., AND JINKS, J. L. 1968. Environmental and genotype environmental components of variability. Heredity, 23, 339-356.

THOMAS, R. L., GRAFIUS, J. E., AND HAHN, s. K. 1970. Transformation of sequential quantitative characters. Heredity (in press).

YATES, F., AND COCHRAN, W. G. 1938. The analysis of groups of experiments. Journ. of Ag. Sci., 28, 556-580. 